\title{
Modelling land-use change for spatial planning support
}

\author{
Eric Koomen • Piet Rietveld • Ton de Nijs
}

Published online: 6 September 2007

(C) Springer-Verlag 2007

\begin{abstract}
Land-use change is a key factor in the development of the human and physical environment. Models of land-use change help understand this intricate system and can provide valuable information on possible future land-use configurations. The latter is crucial for policy makers across the globe that have to deal with such varied topics as: urbanisation, deforestation, water management, erosion control and the like. This paper provides a concise introduction to the current state of land-use models, their applications to spatial policy issues and the main research issues in this field. It thus establishes the background for the six papers that make up this special issue on modelling land-use change for spatial planning support.
\end{abstract}

JEL Classification $\mathrm{C} 15 \cdot \mathrm{C} 53 \cdot \mathrm{R} 14 \cdot \mathrm{R} 52$

\section{Introduction}

Land use is the most clearly visible result of human interaction with the biophysical environment. In all but the most inhospitable and remote mountain ranges, deserts and forests, man has altered the pristine landscape through various types of use. Besides the obvious residential, commercial and agricultural uses, land can also serve pur-

\footnotetext{
E. Koomen $(\varangle) \cdot$ P. Rietveld

Faculty of Economics and Business Administration, Vrije Universiteit Amsterdam, De Boelelaan 1105, 1081 HV Amsterdam, The Netherlands

e-mail: ekoomen@feweb.vu.nl

P. Rietveld

e-mail: prietveld@feweb.vu.nl

T. de Nijs

National Institute for Public Health and the Environment (RIVM), PO Box 1, 3720 BA, Bilthoven, The Netherlands

e-mail: ton.de.nijs@ rivm.nl
} 
poses such as recreation, wood production or biodiversity preservation. The use of land is normally reflected in its outward appearance (land cover), but this relation is more complex than is initially apparent. Land can simultaneously be used for different functions (e.g., agriculture and recreation) or locally have different main functions related to the same cover (e.g., nature reserve and wood production). In fact, many authors therefore explicitly distinguish between land cover and land use (Lambin et al. 2001; Turner et al. 1995). For convenience, we use the term land use predominantly in this and the following papers, referring to both land cover and actual land use.

Changes in land use are amongst the most controversial consequences of human actions, as is clear from the heated debate on urban sprawl (Brueckner 2000; Glaeser and Kahn 2004). The conversion of land may impact soil, water and atmosphere (Meyer and Turner 2007) and is therefore directly related to environmental issues of global relevance. The large-scale deforestation and subsequent transformation of agricultural land in tropical areas are examples of land-use changes with strong impacts on biodiversity, soil degradation and the material resources to support human needs (Lambin et al. 2003). Land-use change is also one of the relevant factors among the determinants of climate change and the relationship between the two is interdependent; changes in land use may impact on the climate whilst climatic change will also influence opportunities for future land-use (Dale 1997; Watson et al. 2000). Planners worldwide thus seek to steer land-use developments through a wide range of interventions that either constrain certain developments (e.g., restrictive greenbelt policies) or favour them (e.g., designation of economic development zones or ecological corridors). They also play an active role in shaping the landscape through their own spatial investments in, for example, infrastructure or the creation of more general funds and subsidies, as is exemplified in the Common Agricultural Policy of the European Union.

For the formulation of adequate spatial policies the involved parties normally make use of models that simulate possible spatial developments. Such models can support the analysis of the causes and consequences of land-use change (Verburg et al. 2004). They facilitate the understanding of the processes at hand and help producing maps of possible future land-use configurations. It is especially the latter possibility that is the topic of the current special issue. As an introduction to the subsequent papers we will briefly discuss here: the typical, policy-related applications of such land-use models, the main characteristics of these models and the current research topics in this field. After providing this general background to the topic of this special issue we will briefly introduce the included papers.

\section{Policy related applications of land-use change models}

Simulations of land-use change provide an important element in studies related to the preparation, development and, to a lesser extent, evaluation of large-scale spatial plans and strategies. Figure 1 presents these subsequent phases of the spatial planning process as cyclical activity, comparable to the spinning top model for public policy evaluation described by Vedung (1997). Below, we will briefly discuss typical land-use model applications for each of these phases of the spatial planning process.

In the preparation phase, simulations of future land use provide policymakers with an impression of the possible developments they face. Based on this knowledge, they 


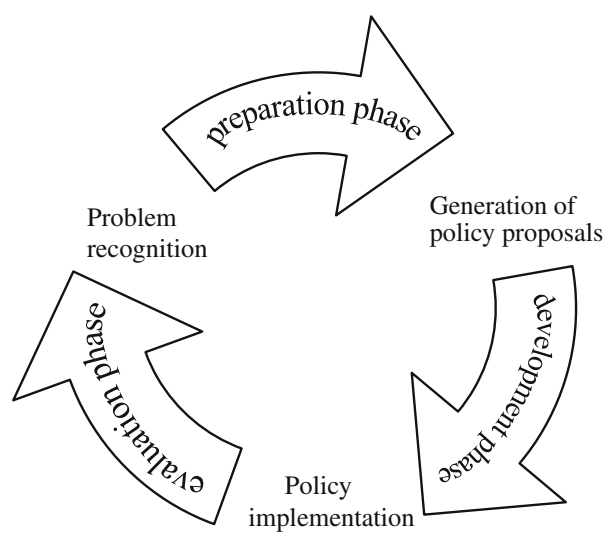

Fig. 1 Representation of the spatial planning process as cyclical activity

can assess the need for action and start drafting appropriate policy proposals. Typical methods to generate these reference or baseline simulations of future land use are trend analysis and scenario studies. Trend analysis can be used to simulate the possible future state of land-use systems on the basis of observed, past spatial developments. By using various statistical techniques, it is relatively easy to represent autonomous land-use developments as an extrapolation of current trends (Schneider and Pontius 2001; Serneels and Lambin 2001). However, such an approach makes no attempt to actually understand the processes that drive land-use change and thus misses a clear theoretical foundation. It is, furthermore, not well suited to simulate long-term developments, non-linear pathways of change or the possible impacts of diverging socio-economic developments. Additional theoretical insights are thus welcomed in these basic empirical-statistical models (Parker et al. 2003; Veldkamp and Lambin 2001) and such examples are provided by, amongst others, Chomitz and Gray (1996) and Geoghegan et al. (2004).

Scenario analyses are especially suited for long-term studies that deal with a wide array of possible developments and the implied uncertainties. By systematically describing several alternative views of the future, one can simulate a broad range of possible spatial developments, thus offering a full overview of the potential landuse alterations. Land-use models are used here to indicate possible future land-use patterns according to the specified scenario conditions, as is demonstrated in numerous applications (De Nijs et al. 2004; Frenkel 2004; Solecki and Oliveri 2004; Verburg et al. 2008). It is important to note here that each individual outlook to the future in a scenario-study will not necessarily contain the most likely prospects, but, as a whole, the simulations provide the bandwidth of possible changes (Dammers 2000). It is not necessary to develop scenarios that are as probable as possible. Instead, the scenarios should stir the imagination and broaden the view of the future. As indicated by Xiang and Clarke (2003) important aspects of useful scenario analyses are: plausible unexpectedness and informational vividness. A specific approach that generates possible alternative solutions to land-use allocation problems is offered by optimisation techniques. These calculate an optimal land-use configuration based on a set of prior conditions, criteria and decision variables (Aerts 2002; Pijanowski et al. 2002). 
Especially the mathematic programming techniques (such as genetic algorithms) that can determine the optimal solution for different, divergent objectives are interesting for policymakers who are interested in the optimal configuration of an area based on different, often conflicting, policy goals (Loonen 2007).

In the subsequent policy development phase, the implementability of different alternatives is assessed. Trend and scenario-based simulations of future land use can help here when they contain reference to envisaged spatial policies. The resulting land-use simulations will then offer a depiction of their possible outcomes. Policymakers can thus be confronted with the likely outcomes of their decisions as is demonstrated by Ritsema van Eck and Koomen (2008). A more specific form of this type of ex-ante evaluations is the dedicated assessment of the land-use impact of a single spatially explicit plan or project. Examples of which are offered by studies on the possible impacts of a new location for a large airport (Scholten et al. 1999) and assessments of the likely consequences of policy reforms for agricultural land use (Sheridan et al. 2007; Van Meijl et al. 2006). These studies might be combined with trend analyses to specifically assess the additional impact of the selected project.

The application of land-use models in the evaluation of the impacts of actually implemented policies and strategies is rare, but Geurs and van Wee (2006) provide an interesting exception in their ex-post evaluation of 30 years of urban development in the Netherlands.

\section{Land-use model characteristics and research priorities}

Recent surveys of operational models for land-use change are numerous. Briassoulis (2000) offers an extensive discussion of the most commonly used land-use change models and their theoretical backgrounds. Waddell and Ulfarson (2003) and Verburg et al. (2004) offer more concise overviews and focus on the future directions of research in this field. A cross-sectional overview of current progress on the analysis of landuse change processes, the exploration of new methods and theories and the application of land-use simulation models is documented in a recent book of Koomen et al. (2007). All surveys show a heterogeneous group of model approaches with considerable differences regarding their theoretical backgrounds, starting points, range of applications, etc. Common characteristics to distinguish between models include their temporal resolution (dynamic vs. static models), spatial resolution (zones vs. grids), central objective (land use vs. land user), simulation approach (deterministic vs. probabilistic), simulation process (transformation vs. allocation) and level of integration (sector specific vs. integrated). A more in-depth discussion on these characteristics and many theories and methods that underlie most current models is provided elsewhere (Koomen and Stillwell 2007). The ongoing advances in computing technology and the rapidly increasing amounts of ever more detailed geographical datasets help modellers worldwide to develop faster and finer scaled models of land-use change. Those developments have made it also possible to explore new data-demanding and computing-intensive modelling approaches that simulate the behaviour of groups of stakeholders or agents (Parker et al. 2003) or microsimulate at the level of individuals (Waddell et al. 2003). New technological developments in the field of 
(three-dimensional) visualisation are particularly helpful in sharing land-use simulation results with policy makers and other stakeholders (Borsboom-van Beurden et al. 2006; Rodríguez et al. 2007).

Combining the strengths of all available concepts, approaches and techniques in stead of elaborating on the approach belonging to the modeller's own discipline is regarded as one of the most important tasks for future research (Verburg et al. 2004). More specifically they list the following priorities in developing a new generation of land-use models:

1. Better address the multi-scale characteristics of land-use systems by encompassing the scale dependencies of the interrelated socio-economic and biophysical processes at various levels.

2. Develop new techniques to assess and quantify neighbourhood effects to better understand the use of such small-scale dependencies that are common in cellular automata based models.

3. Pay explicit attention to temporal dynamics to properly incorporate issues as path dependency, nonlinear pathways of change, feedbacks and time lags. This issue is closely related to the validation of models.

4. Further integration of techniques and methods developed in different disciplines is necessary for modellers to move beyond their own disciplinary traditions and construct truly multidisciplinary models.

5. Assess the effects of land-use change and their feedback on land use following processes as, for example, soil degradation and infrastructure development induced urbanisation.

6. Address the interaction between urban and rural areas that is, for example, manifest in the possibly unequal development of these areas and the emergence of new multifunctional land-use types.

The papers in this special issue deal with a number these issues as will be discussed below.

\section{Layout special issue}

This special issue presents a number of papers that aim to strengthen the link between land-use models and their policy-related applications. The first two papers (Hagoort et al. 2008; Pontius et al. 2008) deal with the calibration and validation of land-use models. A necessary first step to confidently apply any model of land-use change in a policy oriented context. The papers discuss, amongst others, the validity of model outcomes at various scales and the quantification of neighbourhood rules. The following two papers (Shiftan 2008; Verburg et al. 2008) highlight the importance of integrating different modelling approaches, one of them presenting a multi-scale, multi-model approach to analyzing land-use change. The last two papers (Frenkel and Ashkenazi 2008; Ritsema van Eck and Koomen 2008) focus on developing policy-related indicators to assess the effects of land-use change, and give explicit attention to the impacts of urbanisation. Table 1 list the included papers, their relation to the research issues introduced before and the policy themes they try to address. A short introduction to the papers is provided below. 
Table 1 Overview of the included papers, their related research issues and the policy themes they address

\begin{tabular}{|c|c|c|c|c|c|c|c|}
\hline Contribution & $\begin{array}{l}\text { scale } \\
\text { dependencies }\end{array}$ & $\begin{array}{l}\text { Neighbourhood } \\
\text { effects }\end{array}$ & $\begin{array}{l}\text { Temporal } \\
\text { dynamics }\end{array}$ & $\begin{array}{l}\text { Methodological } \\
\text { integration }\end{array}$ & $\begin{array}{l}\text { Land-use } \\
\text { change } \\
\text { effects }\end{array}$ & $\begin{array}{l}\text { Urban rural } \\
\text { interaction }\end{array}$ & Policy themes \\
\hline Pontius et al. & $\mathrm{X}$ & & & & & & $\begin{array}{l}\text { Various policy } \\
\text { themes; methodological } \\
\text { contribution }\end{array}$ \\
\hline Hagoort et al. & & $\mathrm{X}$ & $\mathrm{X}$ & & & & $\begin{array}{l}\text { Various policy } \\
\text { themes; methodological } \\
\text { contribution }\end{array}$ \\
\hline Verburg et al. & $X$ & & & $\mathrm{X}$ & $\mathrm{X}$ & $\mathrm{X}$ & $\begin{array}{l}\text { Urbanisation; } \\
\text { agricultural land } \\
\text { abandonment }\end{array}$ \\
\hline Shiftan & & & & $\mathrm{X}$ & $\mathrm{X}$ & & $\begin{array}{l}\text { Urbanisation and } \\
\text { travel behaviour }\end{array}$ \\
\hline $\begin{array}{l}\text { Frenkel and } \\
\text { Ashkenazi }\end{array}$ & & & & & $\mathrm{X}$ & $\mathrm{X}$ & Urbanisation \\
\hline $\begin{array}{c}\text { Ritsema van Eck } \\
\text { and Koomen }\end{array}$ & & & & & $\mathrm{X}$ & $\mathrm{X}$ & $\begin{array}{l}\text { Urbanisation; } \\
\text { land-use diversity }\end{array}$ \\
\hline
\end{tabular}

\subsection{Calibration and validation of land-use models}

Pontius and a large number of other land-use modelling researchers apply methods of multiple resolution map comparison to quantify characteristics for 13 applications of 9 different popular peer-reviewed land-change models. Each modelling application simulates change of land categories in raster maps from an initial time to a subsequent time. For each modelling application, the statistical methods compare: (1) a reference map of the initial time, (2) a reference map of the subsequent time, and (3) a prediction map of the subsequent time. The three possible two-map comparisons for each application characterize: (1) the dynamics of the landscape, (2) the behaviour of the model, and (3) the accuracy of the prediction. The three-map comparison for each application specifies the amount of the prediction's accuracy that is attributable to land persistence versus land change. Results show that the amount of error is larger than the amount of correctly predicted change for 12 of the 13 applications at the resolution of the raw data. The applications are summarized and compared using two statistics: the null resolution and the figure of merit. According to the figure of merit, the more accurate applications are the ones where the amount of observed net change in the reference maps is larger. This paper facilitates communication among land change modellers, because it illustrates the range of results for a variety of models using scientifically rigorous, generally applicable, and intellectually accessible statistical techniques.

Hagoort, Geertman and Ottens investigate which, how and to what extent landuse related neighbourhood effects play a role in urban dynamics. The inclusion of such effects is the starting point in many Cellular Automata based models of land-use change that support spatial planning. Their research shows that regional and temporal calibration of neighbourhood rules is a refinement in the application this type of land-use models that pays off by increasing the validity of the model outcomes. This questions the appropriateness of land-use model applications that simulate the landuse changes nationally and use the results for regional planning purposes. Regionally 
and temporally calibrated neighbourhood rules better "explain" past land-use changes and their application allows for a better evaluation and justification of spatial policy scenarios and their effects on future land-use dynamics.

\subsection{Integrating different modelling approaches}

Verburg, Eickhout and Van Meijl describe a methodology in which a series of models has been used to link global-level developments influencing land use to local-level impacts. It is argued that such an approach is needed to properly address the processes at different scales that give rise to the land use dynamics in Europe. The global economic model ensures an appropriate treatment of macro-economic, demographic and technology developments and changes in agricultural and trade policies influencing the demand and supply for land use related products while the integrated assessment model accounts for changes in productivity as a result of climate change and global land allocation. The land-use change simulations at a high $\left(1 \mathrm{~km}^{2}\right)$ spatial resolution make use of country specific driving factors that influence the spatial patterns of land use, accounting for the spatial variation in the biophysical and socio-economic environment. Results indicate the large impact abandonment of agricultural land and urbanization may have on future European landscapes. The high spatial and thematic resolution of the results allows the assessment of impacts of these changes on different environmental indicators, such as carbon sequestration and biodiversity. The global assessment allows, at the same time, to account for the tradeoffs between impacts in Europe and effects outside Europe.

Shiftan discusses the advantages and potential of activity-based models for analyzing the effect of land-use policies on travel behaviour. He suggests improvements that will extend the general framework to achieve a better understanding of travellers' responses to various land-use policies and shows its advantages over trip-based models, which simply do not have such capabilities. The improved activity-based approach is illustrated through a case study based on the Portland activity-based model combined with a stated-preference residential choice model. A package of land-use policiesincluding improved land use, school quality, safety, and transit service in the city centre-is introduced, and their effect on household redistribution and regional travel is tested using this integrated framework. The results of this case study show that the effects of the land-use policies introduced had only marginal effects on regional travel.

\subsection{Developing policy-related indicators}

Frenkel and Ashkenazi measure and analyze urban sprawl in Israel, based on a large sample of urban settlements. Higher sprawl rates were found to correlate significantly with higher population and land-consumption growth rates, which imply a higher consumer preference to reside in more sprawling patterns. Variables that are linked with sprawl in Western countries were usually found to be significant in Israel, as well; however, unlike other Western countries, urban sprawl in Israel is rather spatially dispersed, and not necessarily found on the edges of metropolitan areas. Based on 
their findings, the authors call for the implementation of more interdisciplinary sprawl measures such as transportation and accessibility, aesthetic and ecological policies.

Ritsema van Eck and Koomen present two sets of functional indicators that were implemented and tested for the assessment of spatial aspects of future land-use configurations as simulated by a land-use model. This is potentially useful for the ex-ante evaluation of spatial planning policies. The indicators were applied in a Dutch case study and relate to two important themes in Dutch spatial planning: compact urbanisation and mixing of land uses. After a short introduction of these themes, the sets of indicators are presented which are used for their evaluation. These indicators are applied to simulations based on two opposing scenarios for land-use development in the Netherlands up to 2030. The proposed indicators allow for a critical comparison of the land-use patterns in the two scenarios with respect to the selected policy themes. Single indicators capture individual aspects of urbanisation like magnitude, spatial pattern, concentration, compactness and mixing of land uses. It is, however, the combined use of composition and configuration indicators at various scale levels that makes it possible to unambiguously interpret the projected spatial developments.

Acknowledgments We thank the Dutch National research programme "Climate Changes Spatial Planning" and the "Environment, Surroundings and Nature" (GaMON) research programme of the Netherlands organization for scientific research (NWO) for sponsoring the work involved in organizing this special issue. Furthermore, we would like to thank the Organising Committee of the European Regional Science Association for allowing a special "Modelling Land-Use Change" session to be held at the ERSA2005 conference in Amsterdam. It was the success of this occasion that provided the inspiration for this special issue. Last, but not least, we are particularly grateful to the authors and reviewers who contributed their papers and valuable comments to this issue.

\section{References}

Aerts J (2002) Spatial decision support for resource allocation. PhD Dissertation, Universiteit van Amsterdam

Brueckner JK (2000) Urban sprawl: diagnosis and remedies. Int Reg Sci Rev 23(2):160-171

Borsboom-van Beurden JAM, Van Lammeren RJA, Bouwman AA (2006) Linking land use modelling and 3D visualisation: a mission impossible? In: Van Leeuwen J, Timmermans H (eds) Innovations in design and decision support systems in architecture and urban planning. Springer, Dordrecht, pp 85-102

Briassoulis H (2000) Analysis of land use change: theoretical and modeling approaches. In: The web book of regional science (www.rri.wvu.edu/regscweb.htm). Regional Research Institute, West Virginia University

Chomitz KM, Gray DA (1996) Roads, land use and deforestation: a spatial model applied to Belize. World Bank Econ Rev 10:165-174

Dale VH (1997) The relationship between land-use change and climate change. Ecol Appl 7(3):753-769

Dammers E (2000) Leren van de toekomst. Over de rol van scenario's bij strategische beleidsvorming. Uitgeverij Eburon, Delft

De Nijs TCM, de Niet R, Crommentuijn L (2004) Constructing land-use maps of the Netherlands in 2030. J Environ Manage 72(1-2):35-42

Frenkel A (2004) The potential effect of national growth management policy on urban sprawl and the depletion of open spaces and farmland. Land Use Policy 21(4):357-369

Frenkel A, Ashkenazi M (2008) The integrated sprawl index; measuring the urban landscape in Israel. Ann Reg Sci (this issue)

Geoghegan J, Schneider L, Vance C (2004) Temporal dynamics and spatial scales: Modeling deforestation in the southern Yucatán peninsular region. Geojournal 61(4):353-363 
Geurs K, Van Wee B (2006) Ex-post evaluation of thirty years of compact urban development in the Netherlands. Urban Studies 43(1):139-160

Glaeser E, Kahn M (2004) Sprawl and urban growth. In: Henderson V, Thisse JF (eds) Handbook of regional and urban economics: cities and geography, handbooks in economics, vol 4, Elsevier, Amsterdam

Hagoort MJ, Geertman S, Ottens HFL (2008) Spatial externalities, neighbourhood Rules and CA land-use modelling. Ann Reg Sci (this issue)

Koomen E, Stillwell J (2007) Modelling land-use change. Chapter 1. In: Koomen E, Stillwell J, Bakema A, Scholten HJ (eds) Modelling land-use change; progress and applications. Springer, Dordrecht, pp 1-21

Koomen E, Stillwell J, Bakema A, Scholten HJ (2007) Modelling land-use change; progress and applications. In: Geojournal library, vol 90. Springer, Dordrecht

Lambin EF, Turner BL, Geist HJ, Agbola SB, Angelsen A, Bruce JW, Coomes OT, Dirzo R, Fischer G, Folke C, George PS, Homewood K, Imbernon J, Leemans R, Li X, Moran EF, Mortimore M, Ramakrishnan PS, Richards JF, Skanes H, Stone GD, Svedin U, Veldkamp TA, Vogel C, Xu J (2001) The causes of land-use and land-cover change, moving beyond the myths. Glob Environ Change 11(4):5-13

Lambin EF, Geist HJ, Lepers E (2003) Dynamics of land-use and land-cover change in tropical regions. Ann Rev Environ Resour 28:205-241

Loonen W, Heuberger P, Kuijpers-Linde M (2007) Spatial optimisation in land-use allocation problems. Chapter 9. In: Koomen E, Stillwell J, Bakema A, Scholten HJ (eds) Modelling land-use change; progress and applications. Springer, Dordrecht, pp 147-165

Meyer WB, Turner BL (2007) Changes in land use and land cover. Cambridge University Press, Cambridge

Parker DC, Manson SM, Janssen M, Hoffmann MJ, Deadman PJ (2003) Multi-agent systems for the simulation of land use and land cover change: a review. Ann Assoc Am Geogr 93(2):316-340

Pijanowski BC, Brown DG, Manik G, Shellito B (2002) Using neural nets and GIS to forecast land use changes: a land transformation model. Comput Environ Urban Syst 26(6):553-575

Pontius Jr RG, Boersma W, Castella J-C, Clarke K, De Nijs T, Dietzel C, Duan Z, Fotsing E, Goldstein N, Kok K, Koomen E, Lippitt CD, McConnell W, Pijanowski BC, Pithadia S, Mohd Sood A, Sweeney S, Trung TN, Veldkamp TA, Verburg PH (2008) Comparing the input, output, and validation maps for several models of land change. Ann Reg Sci (this issue)

Ritsema van Eck J, Koomen E (2008) Characterising urban concentration and land-use diversity in simulations of future land use. Ann Reg Sci (this issue)

Rodríguez JN, Omtzigt N, Koomen E, De Blois F (2007) 3D visualisations in simulations of future land use: exploring the possibilities of new, standard visualisation tools. Paper for the joint workshop on Visualization and Exploration of Geospatial Data, ISPRS/ICA/DGfK, 27-29 June, 2007, Stuttgart, Germany

Schneider LC, Pontius Jr RG (2001) Modeling land-use change in the Ipswich Watershed, Massachusetts, USA. Agric Ecosyst Environ 85:83-94

Scholten HJ, Van de Velde RJ, Rietveld P, Hilferink M (1999) Spatial information infrastructure for scenario planning: the development of a land use planner for Holland. In: Stillwell J, Geertman S, Openshaw S (eds) Geographical information and planning. Springer, Heidelberg, pp 112-134

Serneels S, Lambin EF (2001) Proximate causes of land-use change in Narok District, Kenya: a spatial statistical model. Agric Ecosyst Environ 85:65-81

Sheridan P, Schroers JO, Rommelfanger E (2007) GIS-based modelling of land-use systems; EU Common Agricultural Policy reform and its impact on agricultural land use and plant species richness. Chapter 21. In: Koomen E, Stillwell J, Bakema A, Scholten HJ (eds) Modelling land-use change; progress and applications. Springer, Dordrecht, pp 375-389

Shiftan Y (2008) The use of activity-based modeling to analyze the effect of land-use policies on travel behavior. Ann Reg Sci (this issue)

Solecki WD, Oliveri C (2004) Downscaling climate change scenarios in an urban land use change model. J Environ Manage 72:105-115

Turner II BL, Ross RH, Sanderson S, Fischer G, Fresco LO, Leemans R (1995) Land Use and land-cover change - science/research plan. IGBP report 35/HDP report 7. Stockholm/Geneva, IGBP/HDP

Van Meijl H, Van Rheenen T, Tabeau A, Eickhout B (2006) The impact of different policy environments on agricultural land use in Europe. Agric Ecosyst Environ 114(1):21-38

Vedung E (1997) Public policy and program evaluation. Transaction Publishers, New Brunswck, NJ

Veldkamp A, Lambin EF (2001) Editorial; predicting land-use change. Agric Ecosyst Environ 85:1-6 
Verburg PH, Schot PP, Dijst MJ, Veldkamp A (2004) Land use change modelling: current practice and research priorities. Geojournal 61:309-324

Verburg PH, Eickhout B, Van Meijl H (2008) A multi-scale, multi-model approach for analyzing the future dynamics of European land use. Ann Reg Sci (this issue)

Waddell P, Ulfarson GF (2003) Introduction to urban simulation: Design and development of operational models. In: Stopher P, Button K, Kingsley K, Hensher D (eds) Handbook in transport, vol 5. Transport Geography and Spatial Systems. Pergamon Press, New York

Waddell P, Borning A, Noth M, Freier N, Becke M, Ulfarson GF (2003) Microsimulation of urban development and location choices: design and implementation of urbanSim. Netw Spatial Econ 3(1):43-67

Watson RT, Noble IR, Bolin B, Ravindranath NHVDJ, Dokken DJE (2000) Land use, land-use change, and forestry. A special report of the Intergovernmental panel on climatic change. Cambridge University Press, Cambridge

Xiang WN, Clarke KC (2003) The use of scenarios in land-use planning. Environ Plann B 30:885-909 